\title{
IMPLEMENTASI PEMBELAJARAN SEJARAH BERMUATAN LOKAL DI SMA NEGERI DI SUMATERA BARAT
}

\author{
Etmi Hardi dan Wahidul Basri \\ Email : etmihardi@yahoo.com \\ Jurusan Sejarah Fakultas Ilmu Sosial Universitas Negeri Padang
}

\begin{abstract}
Abstrak
Penelitian ini berangkat dari kenyataan bahwa pembelajaran sejarah yang bernuansa muatan lokal masih amat jarang diterapkan oleh para guru sejarah di Sekolah Menengah Atas (SMA) Negeri di Sumatera Barat. Padahal dalam kurikulum KTSP dan K-13 yang diterapkan di berbagai sekolah di Indonesia dewasa ini mengharuskan masuknya muatan lokal ke dalamnya. Penelitian ini ingin menelusuri bagaimana materi muatan lokal Sumatera Barat diimplementasikan guru sejarah dalan proses pembelajaran. Penelitian ini dilakukan di beberapa SMA yang berada di Sumatera Barat. Pendekatan yang digunakan bersifat kualitatif, dengan menjaring data dari berbagai sumber, seperti dokumen, observasi, dan wawancara lapangan dengan berbagai pihak yang dapat memberikan informasi. Data yang diperoleh kemudian diolah dengan mengunakan tekhnik analisis interaktif dari Miles dan Huberman. Hasil penelitian menunjukan bahwa pada umumnya guru sejarah di SMA Negeri di Sumatera Barat belum lagi memanfaatkan materi materi sejarah yang mengandung muatan lokal dalam proses pembelajaran. Mereka belum lagi memperkaya materi sejarah yang diajarkan dengan hal hal yang bersifat lokal Sumatera Barat. Terjadinya hal ini disebabkan oleh banyak faktor, baik yang berasal dari guru itu sendiri (internal), maupun berbagai faktor yang datang dari luar guru itu sendiri (eksternal).
\end{abstract}

Kata Kunci: Implementasi, pembelajaran sejarah, bermuatan lokal, di SMA Negeri di Sumatera Barat

\section{Pendahuluan}

Pembelajaran sejarah bersifat unik dan khas, karena sejarah berorientasi kepada masa lalu. Dalam arti kata, sejarah mempelajari peristiwa dan kejadian-kejadian masa lalu. Lebih penting lagi, sejarah merupakan dialog antara masa lalu, masa kini, dan masa depan (Soedjatmoko, 1984:69). Oleh sebab itu tujuan pembelajaran sejarah tidak hanya pada transfer pengetahuan, tetapi juga pada nilai-nilai (afektif) yang berguna pada kehidupan hari ini. Di samping itu, secara pragmatik pengajaran sejarah juga bertujuan untuk meningkatkan kemampuan berpikir inquiri siswa, serta mengaplikasikannya untuk kehidupan hari ini.

Dalam pembelajaran sejarah seorang guru harus mampu mendekatkan anak didik dengan objek, dalam hal ini tentu peristiwa yang dipelajarinya. Contoh-contoh fakta sebaiknya dicari 
dari fenomena yang berada di sekitar mereka. Konsep dibangun dan dikembangkan berdasarkan realitas masa lalu yang juga berada di sekitar mereka. Dengan cara seperti itu akan lebih memudahkan mereka dalam mempelajari dan memaknai peristiwa atau kejadian masa lampau. Di sinilah pentingnya materi sejarah yang bernuansa muatan lokal diberikan sebagai penunjang materi esensial yang ada dalam kurikulum.

Dengan muatan lokal guru dapat mengoptimalkan pengetahuan dan pemahaman sejarah siswa, serta meningkatkan kesadaran sejarahnya. Pembelajaran sejarah dapat diperkayan dengan berbagai peristiwa sejarah yang terjadi di sekitar siswa. Lokalitas disekitar siswa mengandung berbagai peristiwa sejarah yang amat menarik dan kaya untuk dipelajari. Apalagi setiap daerah di Indonesia mengalami perjalanan waktu sejak zaman pra sejarah hingga periode kontemporer. Perjalanan itu terekam di dalam berbagai peristiwa sejarah, yang bukti-buktinya tersebar hampir di seluruh daerah di Indonesia, baik dalam bentuk tulisan, lisan, maupun benda. Dapat dikatakan masing-masing daerah memiliki jejak sejarahnya sendiri-sendiri yang berbeda satu sama lainnya. Muatan lokal juga akan membuat pelajaran sejarah lebih menarik bagi siswa karena fakta-faktanya sangat dekat dengan mereka, sehingga memudahkan mereka untuk mempelajarinya. Kondisi nyata disekitar siswa dapat digunakan oleh guru sebagai cara untuk menggambarkan dan mengantarkan suatu peristiwa sejarah serta memahami berbagai isu sosial yang ada dalam masyarakat. Penelitian Nana Supratna (Jurnal Historia No11 Edisi VI, UPI Bandung, Tahun 2005) telah membuktikan bahwa muatan lokal sangat efektif dalam meningkatkan kemampuan siswa dalam memahami berbagai isu sosial yang ada di sekitarnya.

Demikian pentingnya muatan lokal ini, hingga di dalam pengembangan kurikulum di Indonesia sejak masa lalu hingga dicanangkannya Kurikulum 2013 (K-13) pemerintah selalu mempertimbangkan keberadaannya. Oleh karena itu, pembelajaran sejarah yang berwawasan muatan lokal tetap menjadi perhatian penting dan prioritas utama bagi guru sejarah dalam pelaksanaan pembelajaran, karena akan lebih memudahkan bagi siswa dalam memahami realitas masa lalu bangsanya. Akan tetapi kenyataan yang dijumpai di lapangan para guru sejarah di tingkat Sekolah Menengah Atas (SMA) di Sumatera Barat masih jarang memanfaatkan muatan lokal di dalam proses pembelajaran sejarah. Mereka masih terjebak dalam pemahaman materi sejarah secara literlek sebagaimana yang tertulis dalam buku teks resmi (buku babon), tanpa ada kreatifitas untuk mengembangkannya. 
Dari pengalaman tim peneliti sendiri ketika berhubungan dengan guru-guru sejarah SMA di Sumatera Barat, baik dalam kegiatan MGMP (Musyawarah Guru Mata pelajaran), seminar dan diskusi-diskusi ilmiah, ataupun pembimbingan Praktek Lapangan Kependidikan (PLK) mahasiswa, juga dijumpai kenyataan yang demikian. Para guru sejarah belum mampu mengembangkan muatan lokal ke dalam berbagai Pokok Bahasan (Tema) yang disampaian kepada siswa. Persoalan ini tentunya menarik untuk ditelusuri lebih jauh. Apakah ini disebabkan karena ketidakmampuan mereka untuk mengolah materi sejarah yang bersifat lokal untuk diintegrasikan ke dalam pokok bahasan yang sudah ditentukan dalam kurikulum nasional, ataukah disebabkan oleh faktor faktor lainnya.

Untuk lebih menggali persmasalahan ini secara lebih mendalam, maka diajukan beberapa pertanyaan pokok berikut. Pertama, bagaimana kemampuan guru sejarah dalam mengimplementasikan muatan lokal dalam proses pembelajaran? Kedua, kendala kendala apakah yang mereka hadapi dalam mengembangkan muatan lokal dalam proses pembelajaran?

Penelitian ini bertujuan untuk mengetahui pemahaman guru guru sejarah di SMAN di Sumatera Barat terhadap muatan lokal, serta menganalisis kemampuan mereka dalam mengembangkan materi muatan lokal. Di samping itu juga untuk mengidentifikasi berbagai faktor yang dihadapi guru dalam mengembangan muatan lokal dalam proses pembelajaran.

\section{Metodologi Penelitian}

Penelitian ini dilakukan di Sekolah Menengah Atas (SMA) Negeri di Sumatera Barat. Dari seluruh SMAN yang tersebar di berbagai kabupaten dan kota, akan dipilih secara acak beberapa diantaranya sebagai subjek penelitian.

Data penelitian dikumpulkan lewat studi dokumentasi, observasi, dan wawancara lapangan. Pencatatan dokumen dilakukan diberbagai tempat, baik yang berada di sekolah, maupun di kantor Dinas Pendidikan Sumatera Barat, dan Dinas Dikjar (Pendidikan dan Pengajaran) kabupaten dan kota. Di samping itu juga akan digunakan dokumen pribadi milik guru-guru sejarah. Dalam pada itu juga dilakukan observasi langsung ke dalam kelas untuk mendapatkan data yang valid sesuai dengan tujuan penelitian. Langkah ini kemudian diikuti dengan wawancara secara simultan dan mendalam dari banyak kalangan, seperti guru guru sejarah, kepala sekolah, para pengambil kebijakan, tokoh tokoh pendidikan, serta siswa sendiri. 
Dari data yang diperoleh lalu diklasifikasikan atas unit-unit analisis.Unit analisis ditetapkan berdasarkan rumusan masalah. Dalam penelitian ini teknik yang digunakan adalah model analisis interaktif dari Miles dan Huberman yang terdiri dari tiga komponen yakni: reduksi data, display data dan verifikasi (Sugiyono, 2009: 338-345).

\section{Pembahasan}

Pendidikan merupakan proses budaya yang secara terus menerus senantiasa mengalami perubahan sejalan dengan perkembangan jiwa zaman (zeitgeist). Salah satunya adalah perubahan otoritas sistem pendidikan yang sentralisasi ke desentralisasi. Format otonomi daerah memberi ruang dan kesempatan kepada guru untuk mengembangkan nilai nilai sosial dan budaya yang bersifat lokal.

Dalam Peraturan Pemerintah No. 19 Tahun 2005 sebagai pijakan pelaksanaan Kurikulum KTSP (Kurikulum Tingkat Satuan Pendidikan), muatan lokal diartikan sebagai kegiatan kurikuler untuk mengembangkan kompetensi yang disesuaikan dengan ciri khas dan potensi daerah, termasuk keunggulan daerah, yang materinya tidak dapat dikelompokkan ke dalam mata pelajaran yang ada. Lebih lanjut dalam Permen No. 79 tahun 2014 dinyatakan bahwa muatan lokal merupakan bahan kajian atau mata pelajaran pada satuan pendidikan yang berisi muatan dan proses pembelajaran tentang potensi dan keunikan lokal yang dimaksudkan untuk membentuk pemahaman peserta didik terhadap keunggulan dan kearifan di daerah tempat tinggalnya. Dengan demikian, baik KTSP ataupun K-13 yang diberlakukan di berbagai tingkat pendidikan di Indonesia dewasa ini mewajibkan adanya muatan lokal dalam kurikulum, yang pelaksanaannya diserahkan pada masing masing daerah (desentralisasi).

Khusus untuk mata pelajaran sejarah, materi muatan lokal dapat dikembangkan dan diramu oleh guru dari materi sejarah lokal. Sejarah lokal dapat diartikan sebagai penulisan sejarah dalam lingkup terbatas yang meliputi suatu lokalitas tertentu. Lokalitas disini dapat berbentuk propinsi, kabupaten, kecamatan, desa, atau merujuk kepada etnisitas tertentu (Etmi Hardi, 2015, hal. 2). Secara teoritis batas-batas lokal dapat ditentukan oleh peneliti atau sejarawan, namun ia harus lebih kecil dari skop nasional, ataupun regional (Taufik Abdullah, 2006, hal. 3)

Mempelajari sejarah lokal tentunya berbeda dengan sejarah nasional. Jika literatur sejarah nasional sudah tersedia dalam berbagai buku teks standar, salah satunya adalah Sejarah Nasional 211 | Seminar Nasional Sejarah ke 4 Jurusan Pendidikan Sejarah Universitas Negeri Padang 
Indonesia (jilid I sampai VI), yang telah direproduksi sejak tahun 1975, maka lain halnya dengan sejarah lokal yang literaturnya masih "berserakan" dalam berbagai karya penelitian, baik hasil kerja sejarawan, peminat sejarah, maupun mahasiswa. Dalam hal ini guru sejarah mesti mengumpulkan dan meramu semua literatur itu untuk dapat digunakan dalam proses pembelajaran, sehingga menjadi kurikulum yang bermuatan lokal. Disinilah dibutuhkan profesionalisme guru sejarah sebagai seorang tenaga pendidik. Jika guru sejarah tidak kreatif dan inovatif dalam mengolah berbagai literatur sejarah lokal untuk dijadikan muatan lokal, maka diyakini pembelajaran kurikulum sejarah yang bermuatan lokal tidak akan pernah terlaksana.

Berdasarkan hasil observasi yang dilakukan oleh tim peneliti di 7 SMAN se Sumatera Barat pada bulan Juli dan Agustus 2017 diketahui bahwa dalam proses belajar tidak banyak materi sejarah local Sumatera Barat yang disampaikan guru. Pada saat tim peneliti mengamati guru mengajar di kelas XI IPS dengan materi Penjajahan Hindia Belanda di Indonesia, guru menjelaskan bahwa sejak diberlakukannya Sistem Tanam Paksa di Minangkabau telah menjadikan pemimpin kaum adat sebagai agen kolonial Belanda. Salah satu tanaman yang menguntungkan bagi Belanda waktu itu adalah kopi, karena kopi menjadi primadona di negara Eropa. Akan tetapi materi guru hanya terbatas itu saja, tidak ada penjelasan lain yang bisa diberikan guru kepada siswa yang dapat memperjelas tentang pelaksanaan tanam paksa di Minangkabau. Persoalan itu kemudian dilanjutkan dengan wawancara kepada guru bersangkutan. Sang guru menjelaskan sebagai berikut:

“...sejarah lokal secara khusus tidak terdapat dalam silabus, bahkan di buku siswa ataupun buku guru tidak banyak disinggung tentang sejarah lokal, dan juga tidak diatur didalam kurikulum 2013. Oleh sebab itu guru harus berperan sebagai perantara kepada peserta didik untuk menjelaskan tentang materi sejarah lokal tersebut atau peristiwa sejarah yang terjadi didaerahnya, dikaitkan dengan materi yang dijelaskan saat itu. Para guru sejarah tidak ada yang mampu menjelaskan secara rinci materi yang bersifat lokal kepada siswa. Oleh sebab itu guru hanya terfokus untuk menjelaskan materi yang tercantum dibuku teks yang kebanyakan bersifat Jawa sentris. Akibatnya siswa lebih banyak mempelajari peristiwa sejarah yang berlangsung disekitar daerah Jawa saja, sementara mereka tidak tahu dan lupa dengan sejarah sendiri.

(Wawancara dengan EK pada 29 Agustus 2017 di SMAN 7 Padang)". 
Pada kesempatan lain, Tim peneliti melakukan observasi dan wawancara ke SMAN 1 Lubuk Sikaping. Pada saat observasi tersebut ternyata guru sedang mengajar dengan materi TokohTokoh Daerah dan Nasional dalam memetahankan kemerdekaan Indonesia pada tahun 1948-1965. Dari hasil observasi diketahui bahwa tokoh-tokoh yang dibahas adalah tokoh-tokoh nasional, seperti Jenderal Gatot Soebroto, A.H. Nasution. Tidak ada tokoh-tokoh daerah yang pernah berjuang di Sumatera Barat.

Setelah melakukan observasi peneliti juga mengajukan pertanyaan pada guru yang mengajar di SMAN 1 Lubuk Sikaping tersebut tentang materi sejarah lokal untuk pembelajaran Sejarah Indonesia. Dari jawaban ibu itu diketahui hal-hal sebagai berikut:

“...saya tidak menggunakan sejarah lokal sebagai penunjang pembelajaran dan hanya menjelaskan materi berdasarkan silabus dan RPP. Sejarah lokal dalam buku paket sangat sedikit dibahas kebanyakan juga tidak ada, jadi jika siswa diberi pertanyaan atau tugas tentang sejarah lokal jadi sulit untuk mencari sumbernya, dan saat ujian siswa juga jadi sulit, sebab materi sejarah yang terdapat dalam ujian tentu hanya materi sejarah nasional saja.. (wawancara dengan ibu RNY pada 31 Agustus 2016 di SMAN 4 Padang)".

Dari hasil observasi yang dilakukan di 7 SMAN se Sumatera Barat, dapat disimulkan bahwa tidak semua guru memanfaat materi sejarah lokal Sumatera Barat dalam pembelajaran Sejarah Indeonesia. Dari tujuh sekolah yang diobservasi, hanya dua SMA yang telah memasukkan materi sejarah local Sumatera Barat dalam pembelajarannya.

Setelah dilakkan wawancara dengan guru-guru Sejarah Indonesia yang mengajar di sekolah-sekolah tersebut diketahui beberapa faktor panyebab mereka tidak memasukkan materi sejarah lokal Sumatera Barat dalam proses pembelajaran yang mereka lakukan. Factor-faktor penyebab tersebut adalah: 1) keterbatasan sumber yang membahas tentang sejarah lokal Sumatera Barat; 2) materi sejarah lokal Sumatera Barat tidak ditetapkan secara tegas pada kurikulum 2013 untuk disampaikan pada pembelajaran Sejarah Indonesia; 3) keterbatasan waktu (jam) pelajaran yang membuat guru sulit untuk mengimbangi antara menyampaikan materi inti dan materi sejarah lokal Sumatera Barat; 4) materi sejarah lokal Sumatera Barat tidak termasuk materi ujian sekolah maupun materi ujin nasional. 
Berdasarkan temuan penelitian tersebut maka dipandang perlu untuk menyiapkan materi sejarah lokal Sumatera Barat sebagai bahan untuk digunakan guru Sejarah Indonesia dalam melaksanakan proses pembelajaran. Dengan dimasukkannya materi sejarah lokal dalam pembelajaran Sejarah Indonesia, maka para siswa semakin memahami jati dirinya sebagai generasi muda bangsa

\section{Simpulan}

Dimasukkannya unsur muatan lokal dalam kurikulum pada hakikatnya tidak lepas dari realitas bahwa Indonesia memiliki keberagaman dalam segala hal, terlebih untuk adat istiadat, kesenian, tata cara, tata krama pergaulan, bahasa dan pola-pola kehidupan yang turun temurun dari nenek moyang bangsa Indonesia. Semua itu mesti menjadi rujukan penting bagi anak didik agar tidak kehilangan ciri khas dan jati dirinya. Upaya menjaga kekhasan ini dapat dilakukan oleh guru sejarah melalui penambahan materi sejarah dengan muatan lokal, terutama yang berada dekat dengan lingkungan sekitar dimana siswa berada.

\section{DAFTAR PUSTAKA}

Abdullah, Taufik. 1985. Ilmu Sejarah Dan Historiografi: Arah dan Perspektif.Gramedia. Jakarta. Aditjondro, G.J. 1991. Kurikulum Tersembunyi Sistem Pendidikan Kita. Makalah (Disampaikan dalam Temu Wicara Tentang Peta Masalah Pendidikan, Surabaya).

Gunawan, Ary, H. 2005. Kebijakan-Kebijakan Pendidikan. (Jakarta: Rineka Cipta)

Hamalik, Umar. 2001. Pendidikan Guru Berdasarkan Pendekatan Sistem (Jakarta:Bumi Aksara)

Harjanto. 1997. Perencanaan Pengajaran (Jakarta: PT. Rineka Cipta)

Nana Supriatna. "Konstruksi Pembelajaran Sejarah Lokal Untuk Memahami Isu Isu Sosial", dalam Jurnal Historia, Nomor 11, Edisi VI, Tahun 2005 (UPI Bandung)

Permen Diknas Nomor 79 Tahun 2014

Peraturan pemerintah Republik Indonesia No. 19 Tahun 2005

Raka Jono, T. 1990. "Kurikulim Pendidikan Dasar Menyongsong Abad Informasi Sebuah

Pemikiran Tentang Kurikulum Sekolah Dasar”, dalam Analisa No. 5 tahun XIX. Jakarta: CSIS.

Sjamsuddin, Helius. 2007. Metodologi Sejarah (Yogyakarta: Ombak) 
Soejatmoko. 1984. Dimensi Manusia Dalam Pembangunan.(Jakarta: LP3ES)

Taufik Abdullah, dkk. 2006. Pedoman Penulisan Sejarah Lokal. (Jakarta: Direktorat Nilai Sejarah dan Purbakala Departemen Kebudayaan dan Pariwisata)

Tim Pengembang MKDP Kurikulum dan Pembelajaran UPI. 2011. Kurikulum dan Pembelajaran. (Jakarta: PT. Raja Grafindo Persada)

Wawancara dilakukan dengan sejumlah guru sejarah di SMA Negeri di Sumatera Barat yang kebanyakan mereka namanya keberatan untuk dituliskan

Widja, I Gde. 1989. Dasar-Dasar Pengambangan Strategi Serta metode Pengajaran Sejarah. (Jakarta: Depdikbud)

Widja, I Gde. Pendidikan Sejarah Dan Tantangan Masa Depan. (Pidato Pengukuhan di Universitas Udayana, 1991) 